\title{
SPTBN2 wt Allele
}

National Cancer Institute

\section{Source}

National Cancer Institute. SPTBN2 wt Allele. NCI Thesaurus. Code C106019.

Human SPTBN2 wild-type allele is located in the vicinity of 11q13.2 and is approximately $44 \mathrm{~kb}$ in length. This allele, which encodes spectrin beta chain, non-erythrocytic 2 protein, is involved in the regulation of actin filament function. Mutations in this gene are associated with spinocerebellar ataxia 5 . 